\title{
PENGENALAN POLA GELOMBANG KHAS DENGAN INTERPOLASI
}

\author{
Ari Kusumastuti \\ Dosen Jurusan Matematika Fakultas Sains dan Teknologi \\ Universitas Islam Negeri (UIN) Maulana Malik Ibrahim Malang \\ e-mail: arikusumastuti@gmail.com
}

\begin{abstract}
ABSTRAK
Pengenalan bentuk khas gelombang merupakan masalah yang penting dalam pencitraan suatu bentuk objek yang bervibrasi. Prosedur pengenalan bentuk khas gelombang teridentifikasi dengan suatu Fourier Transform Infra Red. Turunan kedua FTIR merupakan pengenalan bentuk gelombang di daerah sidik jari objek. Permasalahan yang muncul adalah belum teridentifikasi secara detail bentuk khas gelombang tersebut secara visual pada turunan kedua FTIR. Penelitian ini berupaya memberikan jawaban terhadap pencitraan secara detai bentuk gelombang hasil turunan kedua FTIR dengan pendekatan interpolasi. Prosedur interpolasi akan membaca kembali data berpasangan pada turunan kedua FTIR sehingga terbaca bentuk khas gelombang objek. Data berpasangan yang dimaksud adalah bilangan gelombang dan penyerapan. Studi kasus penelitian ini menggunakan data spektra objek yang selanjutnya akan terbaca bentuk khas gelombangnya secara unik dengan interpolasi.
\end{abstract}

Keywords: Interpolasi, bentuk khas gelombang.

\section{PENDAHULUAN}

Kajian pada bidang matematika terapan sangat bermanfaat dalam menjawab permasalahan yang muncul di luar bidang matematika. Banyak permasalahan yang muncul dari berbagai latar belakang disiplin ilmu lain yang penting untuk dianalisis.

Permasalahan identifikasi bentuk vibrasi molekul, misalnya merupakan topik yang sangat membutuhkan peran matematika pada analisis lanjutan. Penelitian pada bidang bioteknologi menggunakan Fourier Transform Infra Red untuk mendeteksi vibrasi molekuler sampai di tingkat sidik jari. Hasil pembacaan FTIR ini menghasilkan data bilangan gelombang (wave number) dan penyerapan (absorbansi). Kelemahan FTIR adalah tidak teridentifikasi visual secara detail bentuk gelombang khas suatu objek sampai di tingkat sidik jari.

Interpolasi merupakan teknik peramalan fungsi dari suatu data berpasangan. Pada penelitian ini masalah interpolasi digunakan sebagai alat untuk mempertajam pengenalan pola gelombang di level sidik jari dari data FTIR. Prosedur interpolasi ini dapat mengenali bentuk khas gelombang secara detail sehingga setiap objek teridentifikasi secara unik bentuk gelombang khasnya.

Prosedur yang digunakan pada penelitian ini adalah;

1. Pengujian secara statistik data turunan kedua FTIR. Uji data dilakukan untuk mendapatkan data berdistribusi normal dan uji pengaruh untuk mendapatkan data yang tidak dipengaruhi oleh waktu pengambilan sampel.

2. Meramalkan data dengan interpolasi. Penelitian ini ditujukan untuk mendapatkan ramalan secara detail bentuk khas gelombang pada suatu objek secara unik.

\section{KAJIAN PUSTAKA}

\section{Interpolasi}

Interpolasi memainkan peranan yang sangat penting dalam metode numerik. Fungsi yang tampak rumit menjadi lebih sederhana bila dinyatakan dalam polinom interpolasi. Interpolasi berguna untuk menaksir harga-harga tengah antara titik data yang sudah tepat. Interpolasi mempunyai orde atau derajat. Interpolasi ada beberapa macam yaitu, interpolasi beda terbagi Newton, interpolasi lagrange, interpolasi spline (Munir, 2006).

Triatmodjo (2002) menambahkan, dalam interpolasi dicari suatu nilai yang berada diantara beberapa titik data yang telah diketahui nilainya. Untuk dapat memperkirakan nilai tersebut, pertama kali dibuat suatu fungsi atau persamaan yang melalui titik-titik data. Setelah persamaan kurva terbentuk, kemudian dihitung nilai fungsi yang berada diantara titik-titik data.

Interpolasi Lagrange digunakan untuk mencari titik-titik antara dari $\mathrm{n}$ buah titik $\mathrm{P}_{1}\left(\mathrm{x}_{1}, \mathrm{y}_{1}\right), \mathrm{P}_{2}\left(\mathrm{x}_{2}, \mathrm{y}_{2}\right), \mathrm{P}_{3}\left(\mathrm{x}_{3}, \mathrm{y}_{3}\right), \ldots, \mathrm{P}_{\mathrm{N}}\left(\mathrm{x}_{\mathrm{N}}, \mathrm{y}_{\mathrm{N}}\right)$ dengan menggunakan pendekatan fungsi polynomial yang disusun dalam kombinasi deret dan didefinisikan dengan: 


$$
y=\sum_{i=1}^{N} y_{i} \prod_{j \neq i} \frac{\left(x-x_{j}\right)}{\left(x_{i}-x_{j}\right)}
$$

Kesulitan utama yang muncul dari proses interpolasi adalah teknis komputasi. Oleh karena itu perlu suatu mekanisme pendukung. Software Matlab dapat digunakan untuk mempermudah pelaksanaan perhitungan interpolasi, bahkan sampai dengan penyusunan fungsi dan penggambaran grafiknya (Djojodihardjo, 2000).

\section{Deret Taylor}

Deret Taylor merupakan dasar untuk menyelesaikan masalah dalam metode numerik, terutama penyelesaian persamaan diferensial. Deret taylor akan memberikan suatu fungsi dengan benar jika semua suku dari deret tersebut diperhitungkan. Persamaan deret Taylor (Triatmojo, 2002):

$$
\mathrm{f}\left(\mathrm{x}_{\mathrm{i}}+1\right)=\mathrm{f}\left(\mathrm{x}_{\mathrm{i}}\right)+\mathrm{f}^{\prime}\left(\mathrm{x}_{\mathrm{i}}\right) \frac{\Delta \mathrm{x}}{1 !}+\mathrm{f}^{\prime \prime}\left(\mathrm{x}_{\mathrm{i}}\right) \frac{\Delta \mathrm{x}^{2}}{2 !}+\mathrm{f}^{\prime \prime \prime}\left(\mathrm{x}_{\mathrm{i}}\right) \frac{\Delta \mathrm{x}^{3}}{3 !}+\ldots \ldots . . .+\mathrm{f}^{\prime \prime} "\left(\mathrm{x}_{\mathrm{i}}\right) \frac{\Delta \mathrm{x}^{\mathrm{n}}}{\mathrm{n} !}+\mathrm{Rn}
$$

\section{Analysis of Variance}

Analisis of Variance atau sering dikenal dengan ANOVA digunakan untuk menyelidiki hubungan antara variabel respons (dependen) dengan 1 atau beberapa variabel prediktor (independen) (Irawan dan Astuti, 2006). ANOVA pada dasarnya terdiri dari dua kelompok. Pengelompokan ditentukan dari jumlah variabel bebasnya. Bila variabel yang akan dianalisis terdiri dari satu variabel terikat dan satu variabel bebas disebut ANOVA satu arah (one way ANOVA). Bila variabel yang akan dianalisis terdiri dari satu variabel terikat dan lebih dari variabel bebas disebut dengan ANOVA dua arah (two way ANOVA) (Hartono, 2004).

One way ANOVA digunakan untuk mengetahui apakah data dari sampel yang ada sudah cukup kuat untuk menggambarkan populasinya, atau apakah bisa suatu dilakukan generalisasi tentang populasi berdasarkan hasil sampel (Harini, 2010). Irawan dan Astuti (2006) menambahkan bahwa, jika hasil analisa diperoleh $p$-value $<\alpha$, maka variabel prediktor tersebut mempunyai hubungan yang kuat, tetapi jika nilai $p$-value yang diperoleh $>\alpha$, maka variabel prediktor tersebut tidak ada hubungan dengan variabel respons.

Output analisis ANOVA ditampilkan dalam window session dengan hipotesis:

$\mathrm{H}_{0}$ : sampel tiap perlakuan sama $\left(\mu_{1}=\mu_{2}\right)$

$\mathrm{H}_{1}$ : ada perlakuan yang tidak sama

Hipotesis awal akan ditolak apabila nilai $\mathrm{F}$

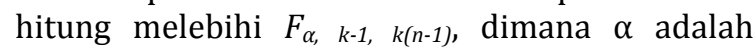
tingkat kesalahan, $k$ adalah banyak replikasi dan $n$ adalah banyaknya perlakuan. Nilai nya dapat dilihat pada table. Selain menggunakan nilai F, dapat juga dilihat dari nilai p-value yang diperoleh. Hipotesis awal akan ditolak apabila nilai $p$-value kurang dari $\alpha$ (Irawan dan Astuti, 2006).

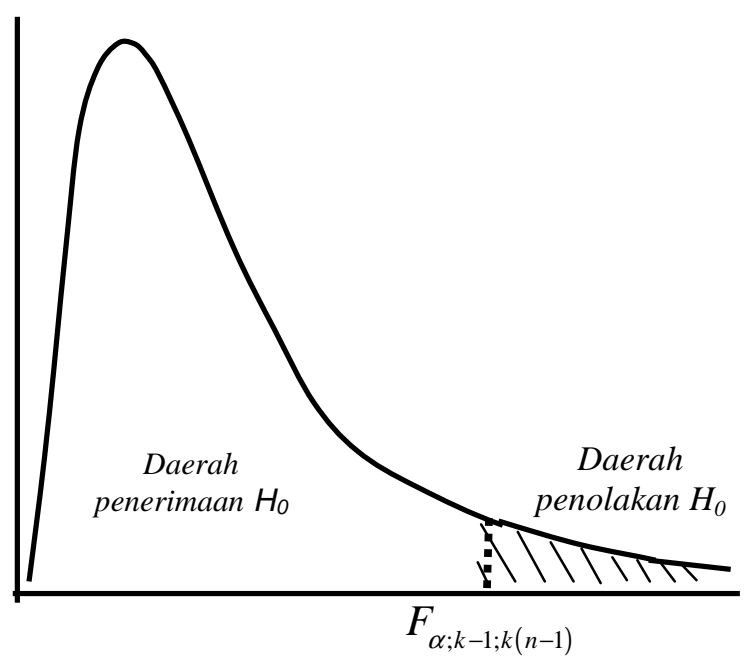

Gambar 1. Grafik daerah penolakan untuk $F_{\alpha, k-1}$, k(n-1) (Irawan dan Astuti, 2006)

\section{Analisis Korelasi}

Korelasi adalah hubungan, begitu pula dengan analisis korelasi yaitu suatu analisis yang digunakan untuk melihat hubungan antara dua variabel atau lebih (Odi, 2008). Analisis korelasi ada beberapa jenis, salah satunya adalah Korelasi Pearson Product Moment (Riduwan dan Sunarto, 2009). Irawan dan Astuti (2006) menambahkan bahwa, koefisien korelasi Pearson berguna untuk mengukur tingkat keeratan hubungan linear antara 2 variabel.

Korelasi Pearson Product Moment (PPM) dilambangkan " $r$ " dengan ketentuan nilai $r$ tidak lebih dari harga $(-1 \leq r \leq+1)$. Tabel interpretasi Nilai r sebagai berikut:

Tabel 1. Interpretasi Koefisien Nilai $r$

\begin{tabular}{cc}
\hline Interval Koefisien & Tingkat Hubungan \\
\hline $0,80-1,000$ & Sangat Kuat \\
$0,60-0,799$ & Kuat \\
$0,40-0,599$ & Cukup Kuat \\
$0,20-0,399$ & Rendah \\
$0,00-0,199$ & Sangat Rendah \\
\hline
\end{tabular}

Sumber: Riduwan dan Sunarto, 2009

Nilai korelasi berkisar antara -1 sampai +1 . Nilai korelasi negative berarti hubungan antara 2 variabel adalah negatif. Artinya, apabila salah satu variabel menurun, maka variabel lainnya akan meningkat. Sebaliknya, nilai korelasi positif berarti hubungan antara kedua variabel adalah positif. Artinya, apabila salah satu variabel meningkat, maka variabel lainnya akan meningkat pula dan apabila nilai korelasi bernilai 
0, artinya tidak ada korelasi (Irawan dan Astuti, 2006).

\section{Second Derivative (2D)}

Program menghitung turunan numerik sangat sederhana. Rumus-rumus turunan dinyatakan sebagai fungsi (Munir, 2006). Derivative dapat digunakan untuk mengumpulkan informasi tentang grafik fungsi. Karena derivative menunjukkan tingkat perubahan dari suatu fungsi, untuk menentukan dimana suatu fungsi naik, maka hanya memeriksa dimana derivativenya positif. Dengan cara yang sama, untuk menemukan dimana suatu fungsi turun, maka hanya memeriksa dimana derivativenya negatif. Titik dimana derivative sama dengan 0 disebut titik kritis. Pada titik-titik ini, fungsi itu konstan dan grafiknya horizontal (Barroroh, 2009).

Dengan membuat turunan spektra, visualisasi dari pantulan spektra dapat ditingkatkan, sehingga pengujian yang lebih baik dapat dimungkinkan. Analisis pada turunan pertama, sangat bermanfaat untuk menempatkan posisi dari puncak, lembah, dan red-edge inflection point (r-eip). Turunan kedua dimaksudkan untuk menentukan posisi dari $r$-eip. $R$-eip adalah spektral region pada batas antara panjang gelombang merah dan infra merah di mana nilai spektral vegetasi meningkat tajam (Ustin et al., 2000 dalam Hartini, 2001). Perbedaan dari posisi puncak, lembah dan r-eip digunakan untuk menjelaskan sifat dari vegetasi.

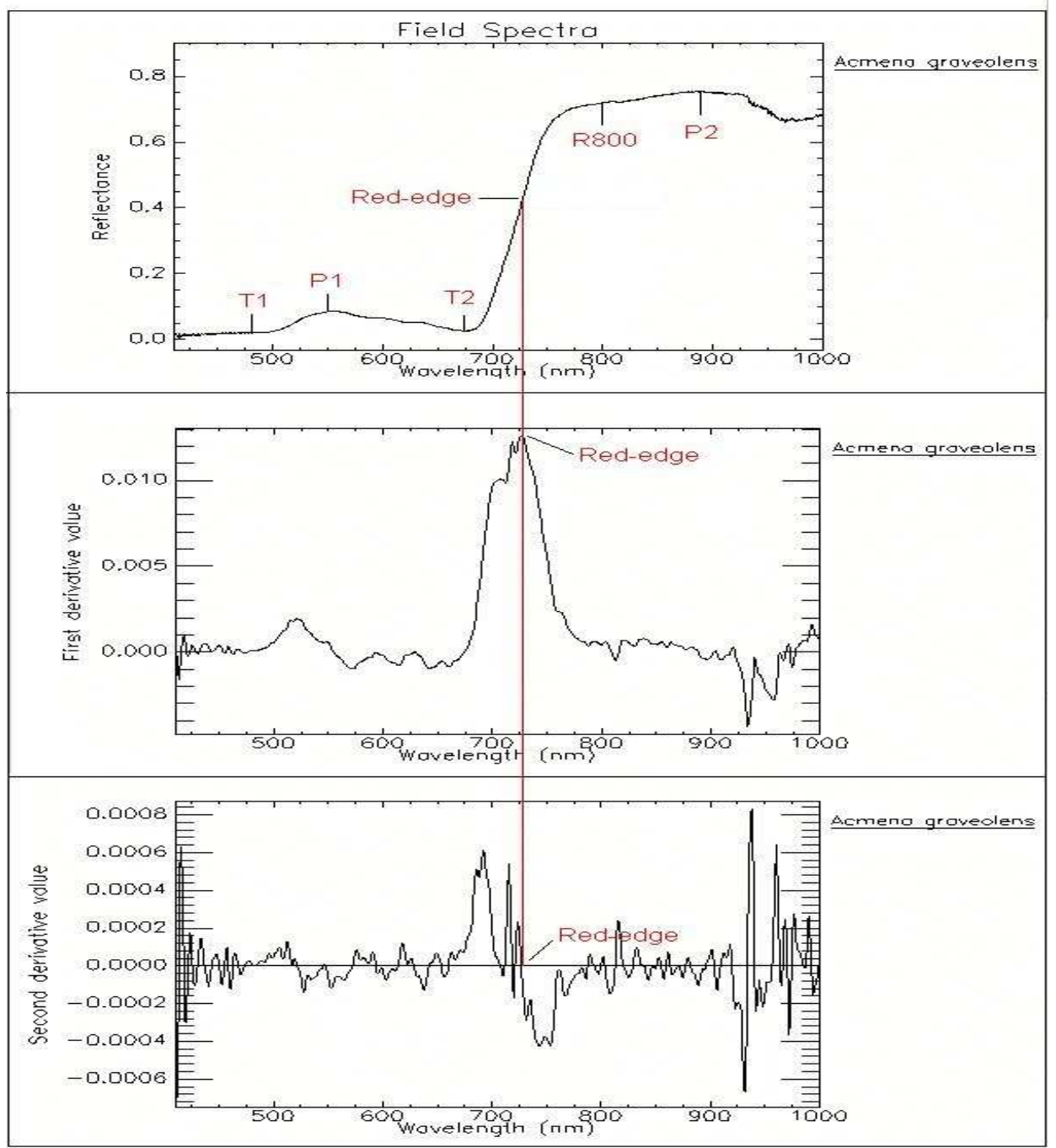

Gambar 2. Posisi dari puncak (P), lembah (T) dan red-edge inflection point (r-eip) pada plot pantulan spektral vegetasi (Hartini, 2001)

Pengujian derivative pertama dan kedua secara esensial memberlakukan logika yang sama, yaitu menjelaskan apa yang terjadi pada derivative $f^{\prime}(x)$ didekat suatu titik kritis $\mathrm{x}_{0}$.
Pengujian derivative pertama mengatakan bahwa maksima dan minima itu berpasangan denfan $f^{\prime}$ melintasi nol dari satu arah ke arah yang lain, yang ditunjukkan oleh tanda dari $f^{\prime}$ dekat $\mathrm{x}_{0}$. 
Pengujian derivative kedua hanyalah pengamatan dengan informasi yang sama ditunjukkan pada kemiringan dari garis singgung $f^{\prime}(x)$ dititik $x_{0}$ (Barroroh, 2009).

\section{Spektroskopi Infra Merah}

Spektroskopi infra merah merupakan salah satu alat yang banyak dipakai untuk mengidentifikasi senyawa baik alami maupun buatan. Bila sinar infra merah dilewatkan melalui cuplikan senyawa organik, maka sejumlah frekuensi akan diserap sedang frekuensi yang lain diteruskan atau ditransmisikan tanpa diserap. Gambaran antara persen absorbansi atau persen transmitansi lawan frekuensi akan menghasilkan suatu spektrum infra merah. Transisi yang terjadi didalam serapan infra merah berkaitan dengan perubahan-perubahan vibrasi dalam molekul (Sastrohamidjojo, 2001). Daerah radiasi spektroskopi infra merah berkisar pada bilangan gelombang $1280-10 \mathrm{~cm}^{-1}$ atau pada panjang gelombang 0,78-1000 $\mu \mathrm{m}$ (Khopkar 1990).

Hayati (2007) menambahkan bahwa, dilihat dari segi aplikasi dan instrumentasi spektroskopi infra merah dibagi ke dalam tiga jenis radiasi yaitu infra merah dekat, infra merah pertengahan, dan infra merah jauh. Daerah spektroskopi infra merah dapat dilihat pada Tabel 2.

Tabel 2. Daerah spektroskopi infra merah

\begin{tabular}{|c|c|c|}
\hline Daerah & $\begin{array}{c}\text { Panjang } \\
\text { Gelombang } \\
\boldsymbol{\mu m}\end{array}$ & $\begin{array}{c}\text { Bilangan } \\
\text { Gelombang } \\
\mathbf{c m}^{-1}\end{array}$ \\
\hline Dekat & $0.78-2.5$ & $12800-4000$ \\
\hline Pertengahan & $2.5-50$ & $4000-200$ \\
\hline Jauh & $50-100$ & $200-10$ \\
\hline
\end{tabular}

Sumber: Hayati (2007)

Energi dalam spektroskopi infra merah dibutuhkan untuk transisi vibrasi, maka radiasi infra merah hanya terbatas pada perubahan energi setingkat molekul. Untuk tingkat molekul, perbedaan dalam keadaan vibrasi dan rotasi digunakan untuk mengadsorbsi sinar infra merah. Jadi untuk dapat mengadsorbsi, molekul harus memiliki perubahan momen dipol sebagai akibat dari vibrasi. Radiasi medan listrik yang berubah-ubah akan berinteraksi dengan molekul dan akan menyebabkan amplitudo salah satu gerakan molekul (Khopkar, 1990).

Ada 2 jenis instrmentasi untuk absorbsi infra merah yaitu, instrumentasi dispersi (konvensional) yang hanya digunakan untuk analisis kualitatif dan instrumentasi yang menggunakan Fourier Transform (FTIR) dapat digunakan untk analisis kuantitatif dan kualitatif (Hayati, 2007).

Spektroskopi FTIR (fourier transform infrared) merupakan salah satu teknik analitik yang sangat baik dalam proses identifikasi struktur molekul suatu senyawa. Komponen utama spektroskopi FTIR adalah interferometer Michelson yang mempunyai fungsi menguraikan (mendispersi) radiasi infra merah menjadi komponen-komponen frekuensi. Penggunaan interferometer Michelson tersebut memberikan keunggulan metode FTIR dibandingkan metode spektroskopi infra merah konvensional maupun metode spektroskopi yang lain. Diantaranya adalah informasi struktur molekul dapat diperoleh secara tepat dan akurat (memiliki resolusi yang tinggi). Keuntungan yang lain dari metode ini adalah dapat digunakan untuk mengidentifikasi sampel dalam berbagai fase (gas, padat atau cair). Kesulitan-kesulitan yang ditemukan dalam identifikasi dengan spektroskopi FTIR dapat ditunjang dengan data yang diperoleh dengan menggunakan metode spektroskopi yang lain (Harmita, 2006).

Delwiche, et al (2007) telah berhasil mengukur jumlah protein glicinin dan $\beta$ conglicinin yang terdapat pada biji kedelai menggunakan Near-Infrared Spectroscopy (NIR) sampai pada batas screening. Sebelumnya protein ini biasa dipisahkan melalui metode ultrasentrifugasi dan elektroforesis. Mossoba, et al (2007) juga telah melakukan penelitian tentang pengukuran kuantitatif asam lemak trans menggunakan spektroskopi infra merah. Metode yang digunakan yaitu melalui pengukuran ketinggian pita absorbsi asam lemak trans pada $966 \mathrm{~cm}^{-1}$ menggunakan metode second derivative (2D). Metode ini berhasil mengidentifikasi dan memisahkan adanya interferensi pita pada 962$956 \mathrm{~cm}^{-1}$ yang dimilki lemak jenuh pada pita asam lemak trans pada $966 \mathrm{~cm}^{-1}$. Keberhasilan pemisahan pita interferensi ini dapat meningkatkan sensitivitas dan akurasi penentuan asam lemak trans pada konsentrasi rendah ( $\leq$ 0.5\% dari lemak total) (Barroroh, 2009).

\section{Pembagian Daerah Spektra Infra Merah}

Daerah spektra infra merah dapat dibagi menjadi 2, yaitu (Mudasir dan Candra, 2008):

1. Daerah frekuensi gugus fungsional

Terletak pada daerah radiasi $4000-1400 \mathrm{~cm}^{-1}$. Pita-pita absorpsi pada daerah ini utamanya disebabkan oleh vibrasi dua atom, sedangkan frekuensinya karakteristik terhadap massa atom yang berikatan dan konstanta gaya ikatan.

2. Daerah sidik jari (fingerprint)

Yaitu daerah yang terletak pada 1400-400 $\mathrm{cm}^{-1}$. Pita-pita absorpsi pada daerah ini 
berhubungan dengan vibrasi molekul secara keseluruhan. Setiap atom dalam molekul akan saling mempengaruhi sehingga dihasilkan pita-pita absorpsi yang khas untuk setiap molekul.

Menurut Hayati (2007), spektroskopi infra merah mengandung banyak serapan yang berhubungan dengan sistem vibrasi yang berinteraksi dalam suatu molekul akan memberikan puncak-puncak yang sangat karakteristik dalam spektra. Corak puncak ini dikenal sebagai "sidik jari" molekul yang merupakan daerah yang mengandung sejumlah besar vibrasi yang tidak dapat dimengerti. Dengan membandingkan spektra infra merah dari dua senyawa yang diperkirakan identik maka dapat dinyatakan kedua senyawa tersebut identik atau tidak.

Akan jauh lebih sulit untuk membedakan ikatan-ikatan tertentu dalam area sidik jari daripada dalam area yang lebih 'bersih' yang berada dalam area dengan bilangan gelombang yang lebih besar. Hal penting dalam area sidik jari ini adalah setiap senyawa yang berbeda menghasilkan pola lembah yang berbeda-beda pada spektrum bagian ini.

\section{HASIL DAN PEMBAHASAN}

\section{Data FTIR}

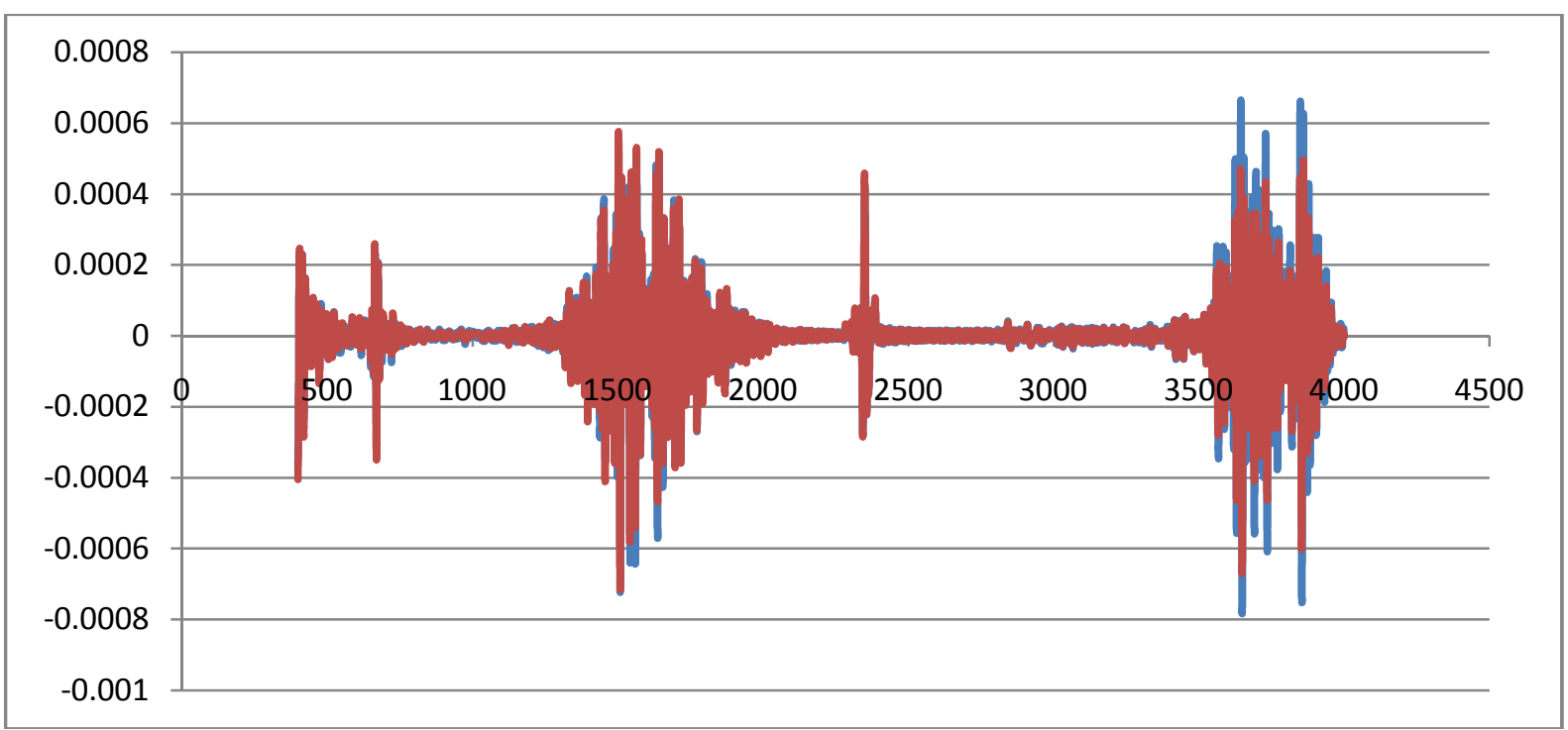

Gambar 3. Data second derivation FTIR

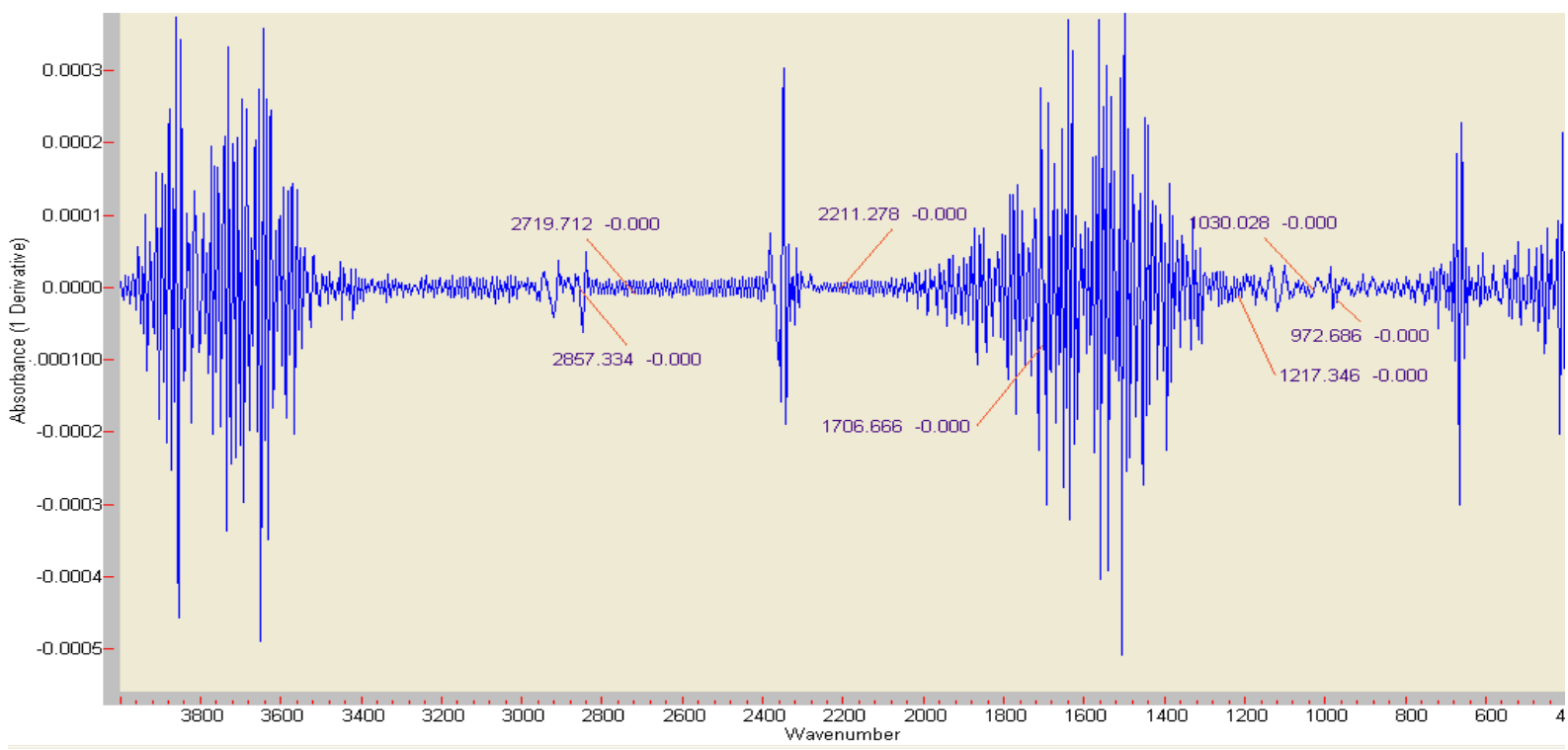

Gambar 4. Hasil pengenalan pola dengan interpolasi 


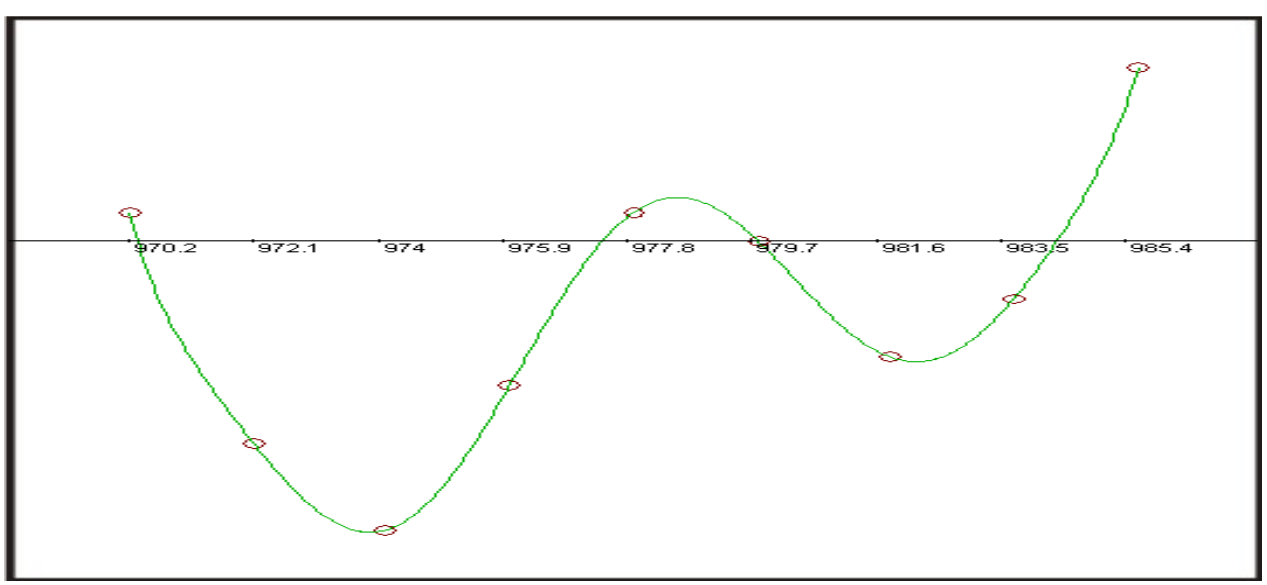

(a). Interpolasi

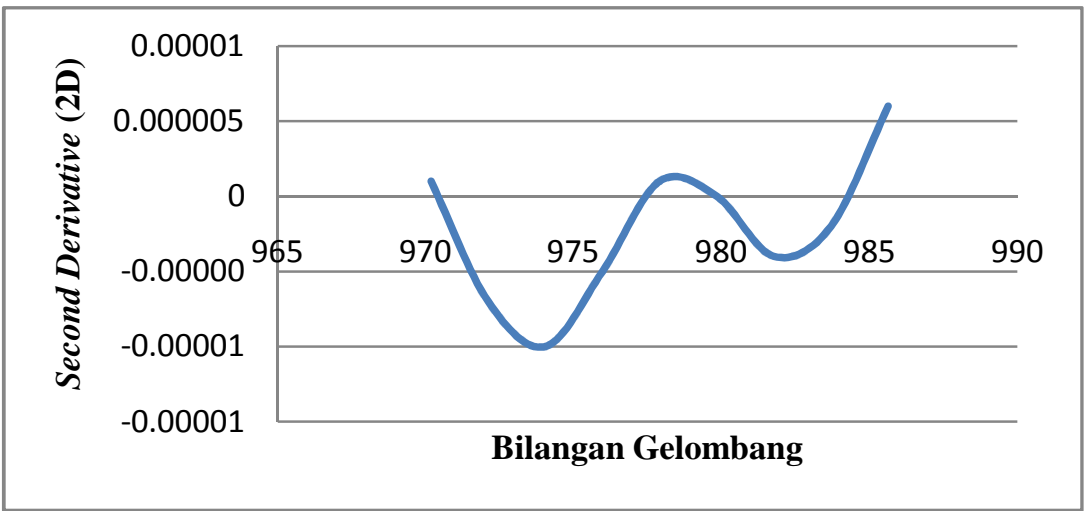

(b). Perbesaran Second Derivative

Gambar 5. a) Hasil analisis interpolasi dan (b) Perbesaran Second Derivative.

Ekspansi deret Taylor dari data second derivation FTIR:

$y=4.7907 e-12 x^{8}-3.7484 e-8 x^{7}+1.2831 e-4 x^{6}-0.2510 x^{5}+306.8267 x^{4}-2.4006 e+4 x^{3}+1.1739 e+8 x^{2}-$ $3.2802 e+10 x+4.0100 e+12$.

\section{PENUTUP}

Pada akhir penelitian ini prosedur interpolasi mampu membaca secara lebih detail dibandingkan dengan second derivation FTIR. Selanjutnya analisis syaraf tiruan dapat di kerjakan sehingga bentuk spectra gelombang objek mampu dikenali untuk mengganti FTIR yang relatif mahal. Prosedur pemberian bobot yang efektif pada langkah JST mampu mengenali pola gelombang suatu objek dengan baik.

\section{DAFTAR PUSTAKA}

[1] Mathews, J.H., (1999). Numerical Methods using Matlab
[2] Chopra, (2002) Numerical Methods for Engineering, Mc Graw Hill

[3] Naseem (2010), Fundamental Numerical Analysis and Error Estimation, Anamaya Publisher, New Delhi

[4] Barroroh (2009). Identifikasi Pola Khas Spektra Inframerah Dengan Second Derivative. Penelitian

[5] Hayati (2007). Dasar-dasar Analisis Spektroskopi

[6] Harini(2010). Praktikum Statistik Elementer

[7] Riduan (2009). Pengantar Statistik Untuk Penelitian. Alfabeta, bandung

[8] Sastrohadimidjojo(2001). Spektroskopi. Liberty, Yogyakarta 